\title{
On the Structure of the Stem of Angiopteris evecta.
}

\author{
BY \\ R. F. SHOVE, \\ Girton College, Cambridge. \\ With Plates XXVIII and XXIX.
}

INTRODUCTION.

$7 \mathrm{HE}$ Eusporangiate Ferns of the present day arouse 1 particular interest, in that they are the living representatives of old Fern types only known to us in the fossil state. Any further knowledge of the structure of these Ferns is therefore of much importance to the palaeobotanist, and particularly is this so in the case of the Marattiaceae, once widespread and abundant, though now only represented by a few genera.

These considerations led to the following account of the anatomy of Angiopteris evecta, Hoffm., which is the result of work on a large stem brought from Ceylon by Mr. Pearson, of Kew, and generously placed at the disposal of Mr. Seward for investigation. In the examination of the roots some of the material used was obtained from the Cambridge Botanic Garden.

The account deals mainly with the anatomy of the stem, together with a few points of interest in the structure of the root. The arrangement and structure of the vascular tissue

[Annals of Botany, Vol. XIV. No. LV. September, rgoo.]

L 1 
in the leaf-bases and stipules have been examined, but only to a small extent, as work in this direction is being done by Mr. Brebner, of the University College, Bristol.

I should like here to express my hearty thanks to Mr. Seward, of Emmanuel College, Cambridge, for supplying me with the material upon which the following account is based, and also for his ready help and kindly interest throughout my work.

\section{Previous Work on the Anatomy of Angiopteris.}

The first important account of work on Angiopteris occurs in the 'Monographie des Marattiacées,' by De Vriese and Harting ' . In this paper several facts are stated in detail, but there is little investigation into the actual course of the vascular strands. The mistake of Harting's in confusing roots traversing the stem with stem-bundles is too well known to be more than mentioned.

In 1863 appeared the important paper by Mettenius, ' Ueber den Bau von Angiopteris.' Mettenius investigated a stem of Angiopteris evecta, Hoffm., but unfortunately the stem was decayed at the base, and had shown at the apex no signs of life for fifteen months ${ }^{2}$, facts which must be taken into consideration in comparing his results with those of later workers.

In this paper the course of the bundles is worked out in great detail; briefly stated, the vascular tissues are considered to form funnel-shaped zones with their lower ends in the axis of the stem, and their higher parts continued out into the leaves. A transverse section of these funnels would give rise to the rings of scattered bundles such as are seen in actual sections of the stem.

Segments from the outermost zone pass off into the leaves, and the gaps thus made are filled up by corresponding segments from the next inner zone. This method of compensation goes on from zone to zone. Mettenius further 
states that a portion of the second zone filling up the gap in the first, due to the presence of a leaf, unites with the segment of the first zone going to the leaf, so that at the point of insertion of the leaf we find anastomoses between the two outermost zones ${ }^{1}$.

Mettenius refers briefly to the structure of the stele in the stem and in the root, and worthy of note is the fact that he finds the protoxylem of the steles. of the stem either central, or situated at the periphery of the wood nearest the organic axis.

In a paper by Russow ${ }^{2}$ in 1872 , there is no investigation into the course of the bundles, but the much debated question of the structure of the root-apex first comes under discussion.

Russow describes two kinds of roots: unbranched airroots with twelve to twenty groups of protoxylem, the outermost elements only being lignified, and branched earth-roots with five groups, the elements of which are lignified to the centre.

According to Russow apical growth in the roots takes place by means of several cells; these are twelve to eighteen in number, prismatic in shape, proportionally large, and rich in protoplasm. The outer apical cells give rise to the cortex and epidermis; the middle apical cells form the axial vascular strands and root-cap tissues.

Longitudinal division occurs at intervals, and the cells thus formed take the place of those which have divided to form the cortex. The weaker earth-roots have a similar method of growth, but the number of apical cells present is smaller.

In connexion with Russow's paper it should be mentioned that the figure he gives of the apical cells in the root of Angiopteris evecta really represents the arrangement of the cells in the root-cap ${ }^{3}$.

In a paper by $\mathrm{Kny}^{4}$, contemporaneous with that of Russow,

1 Mettenius ('64), p. 5io.

${ }^{3}$ Russow ('72), Taf. VIII, Fig. I6I.

2 Russow ('72).

'Kny ('72).

L 12 
it is stated that the roots of the Marattiaceae have one large apical cell, which is surrounded by numerous segments ; these are similar in form and function to the apical cell, but show no transverse divisions.

This view of the apical cells is different from that of Russow, and is elaborated by Holle ${ }^{1}$ in a paper published in 1875. Holle recognizes three forms of apical growth: firstly, the subterranean roots have a four-sided apical cell, from which the neighbouring cells can be clearly seen to arise; secondly, somewhat thicker roots have an irregular apical cell, between which and the neighbouring cells no hard distinction can be drawn; and, thirdly, the large aërial roots have no apical cell, but growth occurs by numerous initial cells in the manner described by Russow.

In a paper by Schwendener ${ }^{2}$ in I 880 we find the view that a median section of the root-tip shows only two apical cells, and hence that apical growth is carried on by only four initial cells.

Bower ${ }^{3}$ confirms this statement, and further says he has traced in a branch-root the development of four initial cells from a single cell of the endodermis.

The most important paper on the root-apex is that by Koch, ' Ueber Bau und Wachstum der Wurzelspitze von Angiopteris evecta, Hoffm. ${ }^{4}$ '

The view here expressed is that no persistent apical cell is present at all, but that one of four particularly large cells assumes the function for a time. It becomes pressed into the organic centre of the root, and divides into four; three of these go on dividing and form meristematic tissue, but the fourth increases in size without division, and, being by pressure made to occupy a central position, repeats the process just described.

This method of growth occurs in small earth-roots; in the thicker earth-roots and in the large air-roots the abovementioned four-celled complex indeed exists in the extreme

1 Holle ('75).

${ }^{2}$ Schwendener ('80).

${ }^{4}$ Koch ('95).

3 Bower ('85). 
apical region, but is not necessary for the production of the root tissues. This is shown by the fact that at some little distance from the root-tip a gap, due to the disorganization of the constituent cells, appears in the midst of the cell complex, and growth is carried on by small meristematic cells which surround the cavity.

Turning now from the consideration of literature dealing exclusively with the root, we find an account by De Bary of a young stem of Angiopteris evecta. This showed a typical bundle-tube with wide foliar gaps, from the lateral margins of which two steles arise, ascend obliquely through the cortex, at the same time undergoing division, and then pass off into the leaves.

Particular points of interest, such as the structure and origin of the mucilage canals, and of the pits, or 'lenticels,' on the leaf-bases and stipules, are discussed in papers by Brebner ${ }^{1}$, Potonié ${ }^{2}$, Hannig ${ }^{3}$, and others. The curious intercellular network of rodlets, due to outgrowths from the walls of the cells, is characteristic of the parenchymatous tissues of the Marattiaceae, and is described by Luerssen ${ }^{4}$, Schenck ${ }^{5}$, Poirault ${ }^{6}$, and Kühn ${ }^{7}$.

\section{External Features.}

In a description of the external features of Angiopteris evecta, no strict line of demarcation can be drawn between the stem proper and the massive leaf-bases with which it is completely covered.

The axis, which is obliquely ascending, ends at the base in a naked blunt cone (Fig. I), but this region shows undoubted marks of erosion, and it is probable that it was more or less covered with leaf-bases similar to those found higher up on the stem. After the removal of the leaves the general form of the stem is seen to be obconical, and in its older parts distinct dorsiventrality of structure is presented.

\footnotetext{
2 Brebner ('95).

4 Luerssen ('73).
2 Potonié ('81).
5 Schenck ('86).
7 Kühn ('89).

3 Hannig ('98).

${ }^{6}$ Poirault ('93).
} 
The upper surface of the naked cone that forms the base of the stem is brown and rough, and bears at intervals fragments of vascular tissue that have been exposed by the wearing away of the softer parenchymatous tissues. The under side, however, shows traces of an original surface, and bears several circular pits (Fig. I, R), which have their origin in the decay of the tissues of the roots.

The stem is about $25 \mathrm{cms}$. in length, reckoning from the tip of the bare base to the summit of the smallest leaves visible from the exterior. In its widest part, that is, nearest the apex, it reaches a diameter of about $8 \mathrm{cms}$., and from this point it diminishes in diameter to about $1 \mathrm{~cm}$. at the base.

The upper surface of the stem is bare for $3 \mathrm{cms}$. from the lower conical end, but here the first leaf (Fig. I, A) occurs, somewhat shapeless owing to the wearing away of the tissues. From this point onwards no free surface is exposed on the upper side of the stem, but leaf-bases, closely wedged together, increase in number and size. The shapeless character of the lower leaf-bases is clearly seen in Fig. I.

The lower surface of the stem bears no leaves for a distance of $8 \mathrm{cms}$. from the base, but is densely covered with roots. These emerge directly from the free part of the stem, and, as will be seen later, the arrangement of the vascular network is modified in this region to facilitate their passage to the exterior. The roots occur for the most part in a definite region on the lower surface of the stem, which bears also one small leaf-base. This leaf-base, together with the lowest of those occurring higher up, is penetrated in every direction by roots, so as to almost obliterate the tissues of the leaf-base proper. Further up the stem the roots occur singly, making their way to the exterior either between or through the leafbases. Correlated with this diminished production of roots is a tendency on the part of the stem to assume a radial rather than a dorsiventral structure.

Owing to the incomplete development of the younger parts of the stem, it could not be determined with absolute certainty whether a radial structure is present in the plant during the 
later years of its growth. However, from the manner of grouping of the young leaves round the apex, this appears to be the case.

The roots vary in length from 14 to $50 \mathrm{cms}$. with a diameter of about I cm.; they are for the most part unbranched, but some bear a few weak branch-roots at long intervals. They are cylindrical in form, with a black wrinkled surface due to the drying up of the tissues, and correspond in structure to the earth-roots of Russow, possessing, however, in general more than five groups of protoxylem.

The apex of the stem is protected by the circinately coiled fronds of the young leaves, each leaf being surmounted by those older than itself.

Turning now to the consideration of the leaves, we find that these occur in the older parts of the stem, mainly on the upper surface, but a few small ones are also found on the under surface, half concealed by numerous roots.

In the younger parts the leaves are arranged round the axis with an approximation to radial symmetry.

The oldest leaf-bases are more or less shapeless masses, owing to decay, but higher up on the stem the leaves display a well-marked differentiation into leaf-base and stipules. In the lower parts of the leaf-base, the petiole and stipules are confluent into one swollen mass, which is united to the stem by a narrow base. This narrow lower region widens out rapidly into a mass which is convex towards the exterior and plane towards the axis of the stem. The leaf-bases, however, vary considerably in size and in method of insertion on the stem, and often, particularly in the smaller leaves, the above-mentioned dorsiventrality of structure is not obvious.

The stipules become separate from the leaf-base proper towards the axis of the stem, and enclose a space, in which the young frond is coiled. The partition joining the stipules is concave inwards, and closely pressed against it is the convex outer surface of a younger leaf. Figs. 3 and 4 show the coiled petiole of the leaf with its enveloping stipules seen in longitudinal and transverse view. 
In Fig. 3, a longitudinal section taken a little to one side of the middle line of the leaf, the outermost stipule (s) is continuous with the tissues of the leaf-base. The wrapping of one stipule (S) over the other $\left(S^{\prime}\right)$ is seen also in Fig. 4, which is a transverse section of the leaf shown in Fig. 3 taken along the line $A B$. The space between the stipules is filled up with ramenta.

The leaves attain their maximum size about the middle of the stem; here the cicatrix left by the fallen petiole measures from 5 to $6 \mathrm{cms}$. in diameter. Even among these, however, a small leaf-base not infrequently occurs.

The surface of the stipules and of the swollen leaf-base is covered with numerous scars (Fig. I, L), somewhat lighter in colour than the other peripheral tissues and slightly depressed below the surface. The scars are oval in outline on the stipules and the sides of the leaf-base, but circular on the convex rounded portion; on the petiole itself they form narrow short streaks or spots. These pits, the so-called lenticels, are small on the petiole, but may attain a diameter of from I to $\mathrm{I} \frac{1}{2} \mathrm{cms}$. on the leaf-base.

In the older leaves the surface of separation of the petiole from the leaf-base is clean-cut, and in it the ends of the steles that have been snapped asunder by the breaking away of the petiole are clearly seen, arranged more or less in circles.

In the younger leaves the lower part of the petiole still remains attached to the base, and its upper end is jagged and broken, where the rest of the leaf was artificially removed.

Finally, in the youngest leaves the petiole still remains circinately coiled, and is completely enclosed by the two overlapping stipules, which are covered with numerous ramenta.

These ramenta are not found on the old leaf-bases, the surface of which is irregularly corrugated, firm in texture, and brownish-black in colour. 


\section{VASCUlar System in the Stem.}

In the determination of the course of the vascular strands in the stem of $A$. evecta, two methods of working were found most successful.

The comparison of successive transverse sections in the first place gave information as to the origin of the leaf-trace bundles, the method of compensation from zone to zone, and the origin and passage to the exterior of the roots.

A clear conception of the arrangement of the vascular tissues into a network could, however, only be gained by the removal of the parenchymatous tissue and the exposure of the strands.

Softening the tissues by boiling in potash was found inexpedient, as, though the labour of removing the parenchyma was thereby much diminished, the vascular strands became too weak to maintain their relative position. It was found most satisfactory to pick away the parenchyma with a sharp knife, and thus expose the vascular tissue.

In accordance with the dorsiventral structure of the stem as seen from the exterior, the vascular network was found to be different in character on the two sides of the stem. This is seen at once by comparing Figs. 5 and 6, which represent the superficial vascular tissue on the upper and under side of the stem respectively. In Fig. 5 strands from more deeply lying vascular zones are also represented.

On the upper surface of the stem the meshes of the network are small and more or less square in outline; the strands destined for the leaves form obliquely ascending portions of the vascular framework, which stand one above another at short intervals. If the dissected stem, shown in surface-view in Fig. 5, is seen from the side, the strands bending out into the leaves appear as projecting and curved bracket-like portions of the stelar lattice-work.

In Figs. 5 and 6 the strands belonging to the same leaf have the same lettering; thus in Fig. 5, the bundles marked 
$e$ belong to leaf I, the bundles marked $c$ to leaf IV, and so on. The sets of leaf-trace bundles are arranged in an irregular spiral round the stem, but the actual phyllotaxis could not be determined owing to the apparent discontinuity of the spiral on the under side of the stem.

Only a few roots are produced by the vascular strands occupying the upper surface of the stem; these come sometimes from the outermost, sometimes from an inner zone.

In Fig. 5 only five roots (R) have been shown, since the position of the remainder was uncertain owing to their removal during the dissection of the stem, but probably about double the number given in the drawing should have been represented.

On the lower surface of the stem the meshes of the network are much drawn out, and there are few anastomoses between the strands; further, the step-like arrangement of the leafbundles as seen in the upper side of the stem is here missing, and the strands going to the leaves are much more parallel with the outermost zone.

The whole tissue of the under side of the stem is thickly penetrated with roots, as is seen in Fig. 6 ; the circular outline of the roots indicates their passage outwards in a direction perpendicular to the longitudinal axis of the plant. The sections of the roots represented in the drawing do not all lie in the same plane, but those in the neighbourhood of the shaded bundles are nearest the axis of the stem, as here the parenchymatous tissue has been removed to the greatest extent. The shaded strands are those belonging to the second vascular zone.

The roots originate, a few in the outer, the majority in the inner zones, but some actually arise from stelar tissue nearer the upper than the under side of the stem, and from there make their way to the lower surface through almost the whole thickness of the stem.

The roots emerge in general at right angles to the surface, or less frequently in an obliquely descending direction. The 
roots represented in Fig. I have an upward direction, but this is due to the action of an artificial pressure.

We will turn now to the consideration of the leaf-trace bundles. These come entirely from the outermost zone of vascular tissue, and in this point the stem now described appears to differ from that examined by Mettenius, who clearly states that in his plant the leaves are supplied with strands coming from the second as well as from the outer zone ${ }^{1}$.

As can be seen from Figs. 5 and 6 , the number and arrangement of leaf-strands vary considerably ${ }^{1}$; it would perhaps convey the truest idea of the arrangement to say that a meshed segment of the outermost zone passes off into a leaf. The difference in character of the vascular tissue on the under and upper side of the stem necessitates a different arrangement of the leaf-trace bundles in the two cases. The meshes formed by the strands in the leaf-bases on the under side of the stem are long and narrow, and in consequence of this the strands themselves do not anastomose so frequently. In Fig. 6 leaf A may be taken as typical of this arrangement, and in Fig. 5 leaf I represents the most general form of the leaf-trace bundles on the upper side of the stem.

Leaving for the future the more detailed account of the foliar strands, we turn to the consideration of the vascular tissue in the inner zones of the stem.

The gap in the outermost zone occasioned by the departure of the leaf-trace bundles is filled up by a segment coming from the next inner zone. This is shown in Fig. 5, where the gap in the superficial zone of vascular tissue, formed by the departure of four strands to leaf $I$, is filled up by a meshed segment rising from the second zone. The gradual passage outwards of this compensating segment from the inner to the outer zone is shown, in the drawing, by a diminution in the degree of shading; the points of union of the two zones are shown at A, B, C, D.

The compensating segment unites right and left of the leaf-base with the outermost zone, and, after continuing for 
a short time in the superficial zone, takes part in the formation of strands for leaves II, III, IV, V. The gap thus caused in the second zone is filled up in a similar way by a segment coming from the third zone. In Fig. 5 the dotted lines show the strands of the third zone; a portion of this passes into the second zone opposite leaf IV at E, F, G, H, and is here darkly shaded. Still continuing its course outwards, the segment passes into the superficial zone at $\mathrm{M}, \mathrm{N}$, and fills up the gap caused by the giving off of strands to leaf IV, and finally shares in the formation of strands destined for leaves V, VI, and VII. It probably shares also in the formation of a fourth leaf, not shown in the drawing, but indicated by the direction of the strand $\mathrm{K}$.

Compensation is thus carried on from zone to zone in the way described by Mettenius, who worked out the relative arrangement of the compensating segments in great detail. The regularity described by him is, however, not apparent in the stem now described.

Fig. 6 shows the compensating segments from the second zone filling the gap in the first, but the large number of the roots and the irregular arrangement of the leaves make it impossible to trace the compensation to greater depths. As in Fig. 5, the shaded strands are those belonging to the second zone.

In considering the foliar strands we find that at some level a transverse section of a leaf-base shows from four to six steles arranged along the convex side of the leaf-base, so that between them and the flattened side of the leaf there is a considerable mass of parenchyma. The strands of the meshed segment corresponding to these steles as seen in transverse section branch and anastomose freely, and soon assume the arrangement of a meshed cylindrical surface. Further anastomoses and divisions then take place, resulting in the formation of the fine stipular threads, and of the concentric zones occupying the higher part of the leaf-base.

Figs. 9-I 2 show a series of transverse sections of a leafbase. At its point of junction with the stem the leaf shows 
six strands arranged as in Fig. 9; these divide and give off branches from their inner surface which turn towards the flat side of the leaf, so that at a distance of about $2 \mathrm{cms}$. from the position of the first section, they represent the appearance shown in Fig. I2.

The initial strands are in general of the same size; the two large side strands described and drawn by Mettenius ${ }^{1}$ do not appear to be present.

The series of transverse sections shown in Figs. 9- 12 corresponds to leaf I in Fig. 6 ; this particular leaf was one of the largest on the stem.

In Figs. 7 and 8 is shown the actual network in the leaves formed by the branching strands ; Fig. 7 shows the vascular tissue of a leaf from the dorsal, Fig. 8 those of a leaf from the ventral side of the stem; in both cases the strands had not attained their full development. The cut ends of the steles lie in the same plane, being exposed in their present position when the corresponding leaf-base was cut from the stem; in Fig. 7, however, the strands $\mathrm{A}$ and $\mathrm{B}$ belong to other leaf-bases. Fig. 8 shows a root (R) originating at the base of a leaf-trace bundle. The different character of the meshes of the network in the leaf according to its position on the stem is clearly seen in the drawings.

It is interesting to compare the course of the vascular strands in A. evecta with that in Kaulfussia and Marattia described by $\mathrm{Kühn}{ }^{2}$.

Kaulfussia possesses a single-meshed cylinder of vascular tissue enclosing a central strand; from the outer zone segments are given off to the leaves, and compensation for these is afforded by segments from the central strand.

The vascular tissue in Marattia is more complicated; here there is a central strand enclosed by two meshed zones, from the outermost of which segments are given off to the leaves, while a compensating segment from the second zone fills up the gap in the first, and a branch from the central strand fills up the gap in the second. Angiopteris differs from

\footnotetext{
${ }^{1}$ Mettenius ('64), p. 512.
}

${ }^{2}$ Kühn ('89). 
Marattia only in having from four to five zones instead of two ; the plan of compensation from zone to zone is identical.

The general scheme of the arrangement of the vascular tissue in Angiopteris is most clearly conceived by considering it in connexion with the insertion of the leaves. The leafbases, which are set in a rough spiral on the stem, show in their lower parts a meshed segment of vascular tissue having the form of part of the surface of a cylinder. This segment passes from the leaf-base into the outermost zone of the stem, uniting right and left with the strands of this zone. Then continuing in an obliquely descending direction, it passes on into the second zone, and so on until it reaches the longitudinal axis of the stem, where it unites with other former leaf-trace bundles and loses all individuality.

Since the leaves are set so thickly on the stem, there is very little vascular tissue that can be definitely stated to belong to the outermost zone; in fact, any part of the outer vascular tissue is more truly considered as forming the lower strands of the leaf-bundles on their way to the interior, than as a portion of a definite meshed cylinder.

A transverse section of the extreme tip of the base of the stem (Fig. I3) shows one large central stele (S); this, at a distance of about half a centimetre from the end, bifurcates, and by further division of the strands thus produced an irregular network arises. It should, however, be remembered that the base of the stem has suffered an unknown amount of denudation, hence the vascular tissue here described forms only part of the original system.

Figs. I $3^{-1} 8$ show a series of transverse sections of the stem taken at distances of about half a centimetre.

The steles are seen to undergo frequent division, and are scattered irregularly through the section; only towards the end of the series does the grouping into concentric circles make itself apparent. Numerous roots (R) are seen to traverse the stem, but their places of origin are, with a few exceptions, not shown, owing to their position higher up in the stem. It should be noted that the roots reach the periphery of the 
section on the left side, which corresponds to the under surface of the stem. The circular outline of the roots at any point indicates their perpendicular descent through the tissues of the stem at this particular part of their course. In Fig. I4 partly decayed steles are shown making their appearance at the periphery of the root; these assume positions further removed from the surface of the stem as the diameter of the sections increases, and are obviously the remaining parts of an outer meshed cylinder of vascular tissue.

The steles shaded in the diagrams are those arising from the branching of the single large stele (S) shown in Fig. I3.

The denudation of the stem has apparently taken place to a greater extent on the upper surface, since it is there that these decayed steles make their appearance in the greatest numbers. Moreover, on the under part of the stem there are traces of an original surface.

Towards the apex of the stem the vascular system maintains the same general characters as in the fully mature parts, and, though on a much smaller scale, a transverse section of the stem at a distance of about $\mathrm{I} \mathrm{cm}$. below the apex is closely analogous to those taken at levels of complete development. The closing up towards the apex of the meshes in the vascular tissue, and the change of the outer network into a closed cylinder, which are described by Mettenius ${ }^{1}$ in his paper on $A$. evecta, are probably to be correlated with the decay in the upper parts of the stem.

By carefully removing the young leaves from the apex of the stem, and noting the position of the leaf-trace bundles, the manner in which these steles make up the roughly concentric circles shown in a transverse section of the stem can be clearly seen.

With regard to the development of the roots from the stem-bundles, there appears to be no regularity of arrangement; some leaf-bases contain no roots at all, while others are so much penetrated by roots making their way to the 
exterior as to show an almost complete absence of parenchymatous tissue. The roots in general originate at points where the steles anastomose; this is so in the case of the roots shown in Fig. 5.

\section{Histological Structure.}

\section{Stem.}

A transverse section of the stem of Angiopteris shows the vascular bundles grouped in roughly concentric circles; the arrangement has been described and figured by Mettenius ${ }^{1}$. The outline of the stem-steles, as seen in transverse section, varies from roughly circular to strap-shaped, the latter arising by the union of two or more of the former.

Union takes place between steles lying right and left of each other, and not between those lying approximately on the same radius, except in connexion with the giving off of leaf-trace bundles or compensating strands. The longer diameter of the strap-shaped steles varies from $\mathrm{I} 5$ to $3 \mathrm{~mm}$.; the more or less circular steles measure from 5 to $2 \mathrm{~mm}$. across.

A transverse section of the stem at any level does not cut all the steles transversely, owing to the oblique dir sction of their course; hence, to determine the position of the protoxylem for a whole section, it is necessary to isolate each stele and to cut it separately. As a result of such procedure it was found that the steles are both mesarch and endarch in structure. Fig. 2 shows the position of the protoxylem groups for a complete transverse section of the stem. The protoxylem elements are recognized in the mature steles by their small size and frequently crushed condition; they appear thus in Figs. 21 and 26.

The investigation of very young steles taken from the apical region of the stem confirms the results obtained from the consideration of the mature bundles. In these young 
steles (Figs. 23 and 25) the protoxylem is found in groups of two or more spiral tracheides situated along the periphery and in the centre of the stele; the number of protoxylemgroups depends upon the size of the stele, the larger steles containing about five or six such groups.

The earliest protoxylem appears along the periphery of the stele; that is, no steles occur in which the central groups are unaccompanied by some at the periphery. The protophloem arises on the outer side of the stele in the form of a discontinuous arc of small, somewhat thick-walled elements (Fig. $23 \mathrm{PP}$ ) which, from the presence of minute granules on their walls, and from their method of attachment to each other, appear to be small sieve-tubes. The position of the protophloem is shown diagrammatically in Fig. 2, and is present in Fig. 25 as a somewhat indistinct layer interior to the large sieve-tubes on the left side of the section.

In a young stele the protophloem and protoxylem are seen, roughly speaking, at the opposite ends of the same radius, the protophloem being towards the periphery of the stem. In very young steles, however, the arc of phloem is found differentiated before any protoxylem elements have been lignified, and this is particularly striking in the steles in the young leaf, where the sieve-tubes are of considerable size.

The arc of protophloem is never completed round the stele, but the next stage in the development of the tissues after the appearance of the protoxylem is the differentiation of large sieve-tubes exterior to the protophloem. A continuous ring of sieve-tubes is finally formed round the xylem, but in certain stages of development, for example in that represented in Fig. 23, the sieve-tubes exterior to the protophloem are larger and thicker-walled than those in the neighbourhood of the peripheral protoxylem.

The lignification of additional tracheides takes place at the same time as the formation of the ring of large sieve-tubes, and in the mature stele we find the concentric structure of the ordinary Fern-type. The ring of sieve-tubes is more con- 
spicuous in the young than in the mature steles, as is seen by comparing Figs. 21 and 25.

The phloem is of greatest breadth on the side of the stele turned away from the axis of the stem, a fact that has been already noted by Mettenius and others. This is not very obvious in the stele shown in Fig. 21, owing to the crushing of the phloem on the outer side, but is seen best by comparing Figs. I9 and 28. Fig. I 9 shows the edge of the stele in the neighbourhood of the protoxylem, and here the phloem-band is narrow. Fig. 28 is a drawing of the outer side of the stele, and here the phloem, made up of large sieve-tubes and protophloem elements, is of considerable width. The greater width of the phloem on the outer side is thus to be attributed to the presence here of the protophloem, which, as has been mentioned above, is never produced on the inner side of the stele.

The protophloem appears in the mature stele as a discontinuous arc of somewhat crushed elements (Fig. $28 \mathrm{PP}$ ).

The centrifugal method of development of the phloem in Angiopteris is contrary to that which prevails in other Ferns. Thus in the steles of the Gleicheniaceae, Polypodiaceae, and Cyatheaceae the protophloem occurs as a similar layer of small crushed elements, but the subsequent sieve-tubes are developed interior to these. In the genus Matonia ${ }^{1}$, the protophloem presents an appearance similar to that in Angiopteris, but here again the further development of the phloem is centripetal.

Further evidence in favour of the view that in Angiopteris the elements in question really constitute protophloem, lies in the fact that no crushed elements occur exterior to the large sieve-tubes, but that these border directly on the cells of the stem-parenchyma (Figs. I 9 and 28).

In a transverse section of the younger parts of the stem the degree of development of the steles is proportional to their distance from the centre: thus a stele in the periphery of the section may have completely lignified xylem, another nearer

\footnotetext{
${ }^{1}$ Seward ('99), Fig. 34.
} 
the centre may possess only isolated groups of spiral tracheides, while a third, nearest of all to the axis of the stem, shows only an arc of protophloem. The method of development of the stele can thus be followed in a single transverse section of the stem.

The concentric structure of the steles with the protoxylem arranged as just described is found in the steles occurring in the leaf-bases, the normal structure of the leaf-bundles only making its appearance where the swollen leaf-base passes over into the petiole proper.

As has been frequently stated by previous investigators, no endodermis is present round the stem steles.

The smallest elements of the protoxylem are spiral tracheides, but somewhat larger tracheides have a form of thickening transitional between spiral and scalariform, which may be described as reticulate. The spiral and reticulate tracheides occur both at the periphery and in the centre of the stele, and are seen in longitudinal section in Fig. $3 \mathrm{I}$.

The large sieve-tubes with their transverse walls are similar in structure to those described by Poirault ${ }^{1}$ for the petiole and root.

As is well known, the stem of Angiopteris is destitute of sclerenchyma, though this is present in the petiole.

Investigations into the character of the actual apex of the stem have not been successful in obtaining any definite result. The stem apparently ends in a flattened or a very slightly convex surface, which is protected by the young leaves with their stipules. In the centre between the youngest leaves the apical tissues are visible as a small white spot, due to the large size of the cells in this region. The actual apex is occupied by several large cells, but the exact arrangement of these could not be determined owing to failure to obtain an accurately transverse section. These cells may be the product of division of an apical cell, or there may be several initial cells as is certainly the case in the apices of the leaves. The vascular strands can be traced up very near the position of these apical cells in the form of strands of small-celled meristem.

${ }^{1}$ Poirault ('94), pp. 139, I94.

$\mathrm{M} \mathrm{m} 2$ 


\section{Root.}

In the plant investigated the roots produced were all of one kind, and similar in structure to the earth-roots of $A$. evecta described by Russow. Transverse sections were cut of twentyfive roots taken at random from the plant, and in these the number of protoxylem-groups varied from ten to thirteen; further, the xylem elements were lignified to the centre of the root. The small number of protoxylem-groups and the total lignification of the xylem is described by Russow for earthroots; besides these, however, he mentions large air-roots, in which from eighteen to twenty protoxylem-groups were present, and in which only the outermost elements of the xylem were lignified. These air-roots appear to be absent in the particular variety of $A$. evecta under examination, but investigation into the structure of the large aërial roots has been carried out on material from the Cambridge Botanic Garden.

After their entry into the ground the large roots branch frequently, more than one side-root being given off at times from the same level. The branch-roots bear no definite relation to the protoxylem-groups in the main root; thus the vascular tissue in the branch may be in connexion with one, two, three or more protoxylem-groups in the mother-root (Fig. 27).

The structure of the earth-roots has been given in detail by Harting and by Mettenius, hence it will be only necessary here to allude to one or two points.

Figs. 22 and 24 show the difference in structure between an earth- and an air-root. The endodermis is well marked in both, though it does not appear very clearly in the photographs, but its structure is better seen in Fig. 20, which is a drawing of a well-preserved root obtained from the Cambridge Botanic Garden. In a longitudinal section of the root the walls of the endodermal cells appear waved, this being due to the occurrence of alternate bars and pits 
on the longitudinal radial walls. This structure has already been described by Mettenius ${ }^{1}$.

In the large air-roots the outer elements only of the xylem become lignified; the inner elements (Fig. $24 \mathrm{~A}$ ) retain the form of tracheides, but their walls are not thickened in any way. In some cases the xylem of the air-roots was lignified half-way to the centre.

In one air-root examined, certain of the rays of unlignified tracheides were not completed at their outer ends by groups of lignified elements, but instead of these, groups of phloem occurred. In one ray there lay successively phloem, a lignified tracheid, and unlignified xylem-elements. The noncompletion of the ray of unlignified tracheides is of interest, since Koch states that in the normal development of the root these more central tracheides are the first to be differentiated ${ }^{2}$, while what is generally regarded as protoxylem is formed later at the outer end of the rays. These small elements at the outer end of the ray are certainly the first to be lignified, whether or not the more central unlignified elements in the shape of tracheides are formed later.

The cortex in the root, as has already been described by Harting and Mettenius, is made up of two regions, the line of division between the two being particularly clear during the passage of the roots through the stem. The inner cells of the cortex bordering on the endodermis are thin-walled, rich in starch, and separated by intercellular spaces, which contain interwoven threads given off from the outer walls of the cells. These are the rodlets of Kühn and others. The cells of the outer cortex have gelatinous walls, no cell-contents, and are separated by no intercellular spaces.

The outermost cells of the cortex in the root are separated from the cortical cells of the stem by a layer of gelatinous substance, apparently similar in nature to that which constitutes the cell-walls in the outer cortex. In the older roots the distinction of the cortex into two layers is not so apparent, owing to the fact that the cells of the outer cortex 
are crushed together to form a protective tissue. Among these crushed elements occur at intervals short lignified cells ; these are thick-walled, with pointed ends, and probably function as idioblasts for mechanical support.

In two cases, probably anomalous but certainly of interest, the roots of Angiopteris showed dichotomous branching. The first case was that of a large air-root obtained from the Cambridge Botanic Garden; the two branch-roots produced by the dichotomy of this measured only about $\mathrm{I} \mathrm{cm}$. in length, hence their vascular elements had not been differentiated, and in fact the branches could be hardly said to constitute more than root-tips. The mother root was $1 \mathrm{~cm}$. in diameter, and possessed twenty protoxylem-groups, the outer elements only of the xylem-rays being lignified. In this case the connexion between the protoxylem-groups of the motherroot, and of its branches, could not be determined, owing to the non-lignification of the protoxylem in the secondary roots, but in the second case of dichotomy observed the relation was satisfactorily worked out.

The dichotomous root in question was a side-branch of an earth-root, also from the Cambridge Botanic Garden. The main root was $.65 \mathrm{~cm}$. in diameter, possessed thirteen groups of protoxylem, and had lignified tracheides half-way to the centre. This produced a side-root, $.25 \mathrm{~cm}$. in diameter, possessing seven protoxylem groups, which shortly after its exit from the cortex of the mother-root underwent dichotomy. The products of the division were roots, $\cdot 2 \mathrm{~cm}$. in diameter; each possessed five groups of protoxylem, and its xylemelements were lignified half-way to the centre. Fig. 30 shows a transverse section of the side-branch just after its exit from the main root; the xylem groups $\mathrm{A}, \mathrm{B}, \mathrm{C}$ are larger than the others. Fig. 29 shows the stele of the side-root undergoing dichotomy; the xylem groups A, B, C have each divided into two; $\mathrm{A}$ has given rise to 1 and $2, \mathrm{~B}$ to 3 and 4 , and $\mathrm{C}$ to 5 and 6 . Two new steles have been formed, each containing five groups of protoxylem.

This method of branching is certainly not general in the 
roots of Angiopteris, but in connexion with these cases it may be of interest to mention that Mr. Seward has noticed apparent dichotomy in a petiole of an Angiopteris plant in the Botanic Garden at Leipzig.

The origin of the roots from the vascular strands of the stem has not been worked out, but it may be suggested that there is some relation between the roots and the central protoxylem in the stem stele. Casual sections showing the origin of the roots confirm the statement given by Mettenius of the presence of short, irregularly-shaped scalariform tracheides at the junction of the root and the stem-stele ${ }^{1}$.

The apices of the roots found on the plant under investigation were either absent, or in a too much decayed condition to afford any information as to their structure. My investigations into the root-apices obtained from the plant in the Cambridge Botanic Garden are confirmatory, as far as they go, of the views expressed in Koch's paper.

In the stouter air-roots a gap occupies the general position of the apical cells, and growth is carried on by the tissue of meristematic cells which surround the cavity. The gap, which originates near the apex by the disorganization of the large apical cells, persists for a considerable distance in the centre of the root-stele.

In somewhat smaller roots, several large cells are present at the junction of the root-cap tissue with that of the root proper, but it was not possible to determine their actual relation to each other. In the small branch-roots growth is apparently carried on by means of one apical cell, as described by Holle; this method of growth is indicated by the arrangement of the cells in the apical region, as seen in transverse section, in roughly concentric circles, but its existence can hardly be said to be definitely proved.

\section{Leaf.}

There is no intention in the present paper to give any detailed account of the leaves of Angiopteris, but a few points 
of interest may be mentioned with reference to the structure of the vascular tissue in the leaf-bases.

The method of division of the initial leaf-strands into a network has been already described, and the superficial part of the network is shown in Figs. $3^{2}$ and 33. Fig. 33 represents the superficial tissue from the inner flat side of the leaf-base; the strands enclosed within the space $a, b, c, d$, are those which occupy the connate part of the stipules, and those at $p, q, r, s$, are branches making their way inwards to the petiole proper; the other petiolar bundles arise from the inner surface of the superficial vascular tissue and are not therefore represented in the diagram.

Fig. 32 shows the superficial vascular strands from the outer convex surface of the leaf-base; these are not represented in perspective, but as spread out over a plane surface. The cut ends of the bundles represented as lying along the arc $a b$ are those of branches destined for the petiole; it is obvious that the petiole is thus continuous with the convex side of the leaf-base. At $\mathrm{S}$ are shown the fine strands belonging to the stipules; these form a network with long drawn-out meshes, and are accompanied by numerous secretory passages. The secretion, probably tannin, is contained in sacs or cells arranged in longitudinal rows; these are seen particularly well in a median section of the root-tip.

In the leaf the structure of the stele is that of the ordinary stem type, with the exception of the absence of the arc of protophloem. As in the stem, the vascular elements first differentiated form an arc of sieve-tubes on the side of the stele furthest from the centre of the organ, but in the case of the leaf these are of considerable size, and later form part of a continuous ring.

Soon after the formation of the protophloem, the protoxylem appears along the opposite side of the stele, one group onlybeing formed in the case of the smaller, semi-lunar-shaped steles.

The ultimate bundles in the stipules show no recognizable phloem, but consist of a few tracheides, surrounded by smallcelled parenchyma; frequently one tracheid only is present in the stipular steles. 


\section{Conclusion.}

Since the anatomical structure of the stem of Angiopteris evecta has been described in most detail by Mettenius, it is of interest to compare with his results those now obtained.

The arrangement of the vascular strands in a series of inverted funnel-shaped zones is the same in both stems, but the closing up of the strands into continuous rings in the upper part of the stem, in the way described by Mettenius, must certainly be attributed to the unhealthy life of the plant for some time before its abandonment to the purposes of scientific research. There was not the slightest trace of such an altered structure in the apical regions of the plant from Ceylon.

Further, my investigations show that the leaf-trace bundles arise from superficial vascular tissue alone, and that the steles of the second zone do not share in the formation of the foliar strands, which are indefinite in number and position. This was not the case in the stem described by Mettenius, for here two bundles from the second zone passed off into each leaf, and the foliar strands were constant in number and arrangement. The difference in character of the foliar bundles in the upper and under leaves in Mettenius' plant is, of course, to be correlated with the difference in the vascular system in the stem in the two cases.

The stem just described presented definite dorsiventrality, both in its external characters and internal structure. The roots were produced in great numbers on a certain part of the lower surface of the stem, and diminished in number towards the apex. This latter fact is also noted by Mettenius, who attributes it to the altered conditions in the nutrition of the plant ${ }^{1}$.

The wearing away of the base of the stem described in the preceding pages did not allow of any conclusion as to the original structure of the vascular system in this part; 
the arrangement must be examined in the case of some plant that has not undergone decay.

With regard to the internal structure of the stem-stele, the chief point of interest is the anomalous position of the protophloem.

The centrifugal growth of the phloem is contrary to that described for most other Ferns, and it would be of interest to examine the development of the steles in the other members of the Marattiaceae to determine whether in them a similar method of development is repeated. The histological structure of the stem-steles in Kaulfussia and Marattia has been described by Kühn, but no mention is made of the protophloem ; this, however, is so indistinct in the mature bundles that, unless its position had been first determined in the young steles, its presence might well have been overlooked.

The number and position of the protoxylem-groups has been worked out for a complete transverse section of the stem, and the mesarch and endarch structure of the steles has been further confirmed by the position of the spiral and reticulate tracheides as seen in longitudinal sections of the steles.

In the apical regions of the stem the presence of several initial cells was satisfactorily demonstrated, but the exact number of these and their method of division still remain to be determined.

Investigations into the structure of the roots on the plant examined show that these are of one kind and correspond in structure to the earth-roots described by Russow; the stem was apparently destitute of air-roots.

Owing to the impossibility of obtaining the prothalli of Angiopteris, no examination could be made into the structure of the seedling stems; such work is of course necessary to render complete the account of the stem-anatomy. 


\section{BIBLIOGRAPHY.}

De BARY, A., '84 : Comparative Anatomy of Phanerogams and Ferns. Oxford, I 884 .

Bitter, G. : In Engler and Prantl, Die nat. Pflanzenfamilien. I. Teil, 4. Abteilung, I900.

Bower, F. O., '84 : On the Comparative Morphology of the Leaf of the Vascular Cryptogams and Gymnosperms. Phil. Trans. Royal Soc. London, I884. Part II.

'85: On the Apex of the Root in Osmunda and Todea. Quarterly Journal of Microscopic Science, I885, vol. xxv.

Brebner, G., '95 : On the Mucilage Canals of the Marattiaceae. Journ. Linn. Soc. London, xxx, p. 444, I895.

Gardiner, W., '85 : The Continuity of the Protoplasm in Plant Tissue. Nature, I 885 , p. 39 I.

Hannig, '98: Ueber die Staubgrübchen an den Stämmen und Blattstielen der Cyatheaceen und Marattiaceen. Bot. Ztg., I 898 .

Holle, '76 : Ueber die Vegetationsorgane der Marattiaceen. Sitzb. d. kgl. Gesellschaft der Wissensch. z. Göttingen, I876. Bot. Ztg., I876, p. 2 I5.

Karsten, '47 : Die Vegetationsorgane der Palmen. Schriften der Königl. Akad. der Wissenschaften. Berlin, I 847 .

Klebahn, H., '84 : Die Rindenporen. Jen. Zeitschr. für Naturwissensch., vol. xvii, 1884 .

Kосн, L., '95: Ueber Bau und Wachstum der Wurzelspitze von Angiopteris evecta. Pringsh. Jahrb., vol. xxvii, I895.

KüHN, R., '89 : Untersuchungen über die Anatomie der Marattiaceen und anderer Gefässkryptogamen. Flora, I 889 .

LeClerc du Sablon, '90: Recherches sur la Formation de la Tige des Fougères. Ann. Sci. Nat. (7), vol. ii, p. I.

Luerssen, C., '73 : Ueber die Spaltöffnungen von Kaulfussia Bl. Bot. Ztg., i873, p. 625 .

'73 : Ueber centrifugales locales Dickenwachstum innerer Parenchymzellen der Marattiaceen. Bot. Ztg., I873, p. 64I and Plate VI. '75: Untersuchungen über die Intercellularverdickungen im Grundgewebe der Farne. Sitzb. d. Naturf.-Ges. Leipzig, I 875 .

Mettenius, G., '64 : Ueber den Bau von Angiopteris. Abhand. K. Sächs. Ges. Wiss., vol. vi, p. $50 \mathrm{I}$.

Poirault, G., '94: Recherches anatomiques sur les Cryptogames vasculaires. Ann. Sci. Nat., Bot. (8), t. xviii, p. I I 3, I 894.

Potonik, H., '81 : Anatomie der Lenticellen der Marattiaceen. Jahrbuch. d. Bot. Gartens z. Berlin, vol. i, p. $30 \%$.

ReINke, '72: Zur Geschichte unserer Kenntnisse vom Bau der Wurzelspitze. Bot. Ztg., I 872 .

Russow, E., '72 : Vergl. Untersuchungen. Mém. Acad. Imp. St.-Pétersbourg (7), vol. $x i x$. 
SACHS, J., '74 : Lehrbuch der Botanik, 4. Aufl. Leipzig, I874, p. 4I5.

Schenck, H., '86: Ueber die Stäbchen in den Parenchymintercellularräumen der Marattiaceen. Ber. der deutsch. Bot. Gesellsch., I 886.

Schwendener, S., '82: Ueber Scheitelwachstum der Phanerogamenwurzeln. Sitzb. Königl. Akad. d. Wiss. Berlin, 1882 .

Seward, A. C., '99: On the Structure and Affinities of Matonia pectinata. Phil. Trans. Roy. Soc. London, 1899 .

Van Tieghem, P., '91 : Traité de Botanique. Paris, I89I.

DE VRIEse, P., and Harting, '53: Monographie des Marattiacées. Leide et Düsseldorf, 1853 .

\section{EXPLANATION OF PLATES XXVIII AND XXIX.}

\section{Illustrating Miss Shove's paper on Angiopteris.}

PLATE XXVIII.

Angiopteris evecta.

Fig. I. Piece of stem showing bare base, roots (R), and lower leaves. L, lenticels; P, petioles; s, stipules.

Fig. 2. Diagrammatic transverse section of mature stem after removal of leaves. R, roots ; P.P, protophloem; P.X, protoxylem.

Fig. 3. Longitudinal section of young frond. $s$, outer stipule; $s^{1}$, inner stipule.

Fig. 4. Transverse section of young frond taken along the line $A B$ in Fig. 3 . $P$, circinnately coiled petiole; $S^{1}$, inner stipule; $S$, onter stipule. Line $A^{1} B^{1}$ corresponds in position to line $\mathrm{AB}$.

Fig. 5. Portion of the vascular network from the upper side of the stem. $\mathrm{R}$, roots.

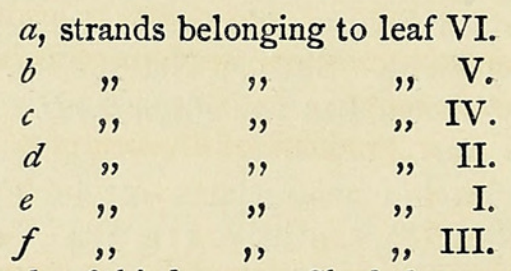

Dotted lines show strands of third zone. Shaded strands belong to second zone.

A, B, C, D, points of union of strand from second zone, compensating for the departure of the strands $e$ of the first zone into leaf $\mathrm{I}$, with the vascular tissue of first zone. M, N, P, similar points in case of strand compensating for the departure of the strands $c$ into leaf IV.

E, F, G, H, points of union of strands of third zone with those of second zone. 
Fig. 6. Portion of the superficial vascular tissue from the under side of stem $\mathrm{R}$, roots.

Shaded strands are those belonging to second zone.

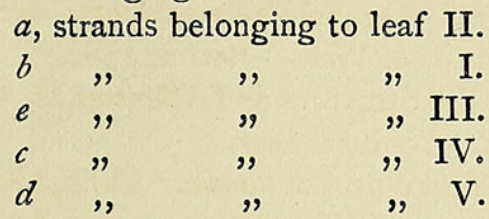

Fig. 7. Vascular strands of leaf-base from upper side of stem. A, B, branches to two other leaves.

Fig. 8. Vascular strands of leaf-base from lower side of stem. R, root.

Figs. 9, IO, I I, I2. Series of transverse sections of leaf-base showing branching of steles. R, root. Series is that of leaf I in Fig. 6 .

Figs. I 3-I 8. Series of transverse sections from base of stem. Shaded steles are those derived from branching of original stele (s) in extreme base of stem.

Fig. 19. Transverse section of stelar tissue on side nearest the centre of stem. P. $\mathrm{x}$, protoxylem; s, sieve-tubes; C, cortex. $\times 100$. Arrow points to centre of stem.

\section{PLATE XXIX.}

Fig. 20. Transverse section of stele in air-root. C, cortex; E, endodermis; P. $x$, protoxylem; P, phloem; R, resin-passage; A, unlignified tracheides. $\times 100$.

Fig. 2r. Transverse section of large stem stele. P. $X$, protoxylem; s, sievetubes. $\times 25$.

Fig. 22. Transverse section of earth-root. E, endodermis. $\times 40$.

Fig. 23. Transverse section of young stem stele. S, sieve-tubes; P. P, protophloem ; P. X, protoxylem. $\times 100$.

Fig. 24. Transverse section of air-root. $\mathrm{x}$, peripheral group of lignified tracheides; $\mathrm{A}$, unlignified tracheides; $\mathrm{P}$, phloem; $\mathrm{E}$, endodermis. $\times 40$.

Fig. 25. Transverse section of young stem stele. P. X, protoxylem; P.P, prophloem; s, sieve-tubes. $\times 40$.

Fig. 26. Transverse section of small circular stem stele. P. $x$, protoxylem; S, sieve-tubes. $\times 40$.

Fig. 27. Diagrammatic transverse section of lateral roots. $x$, xylem rays in mother-root; P, pith ; E, endodermis ; C, cortex in lateral roots.

Fig. 28. Transverse section of stelar tissue on outer side. S, sieve-tubes; P. P, protophloem; x, xylem. $\times$ I00. Arrow points to centre of stem.

Figs. 29, 30. Diagrammatic transverse sections of dichotomising root. A, B, C, larger rays of xylem in main root:

$$
\begin{aligned}
& \text { I, } 2 \text {, products of division of A. } \\
& 3,4, \quad " \quad " \quad \text { B. } \\
& 5,6, \quad " \quad \text { C. }
\end{aligned}
$$

Fig. 3I. Protoxylem elements from stem stele. s, spiral tracheid; R, reticulate; $\mathrm{K}$, scalariform.

Fig. 32. Superficial vascular network from convex side of leaf-base. $a-b$, petiolar bundles; s, stipular bundles.

Fig. 33. Superficial vascular strands from flat side of leaf-base. $a, b, c, d$, encloses strands which occupy partition joining stipules; $p, q, r, s$, strands going to petiole. 


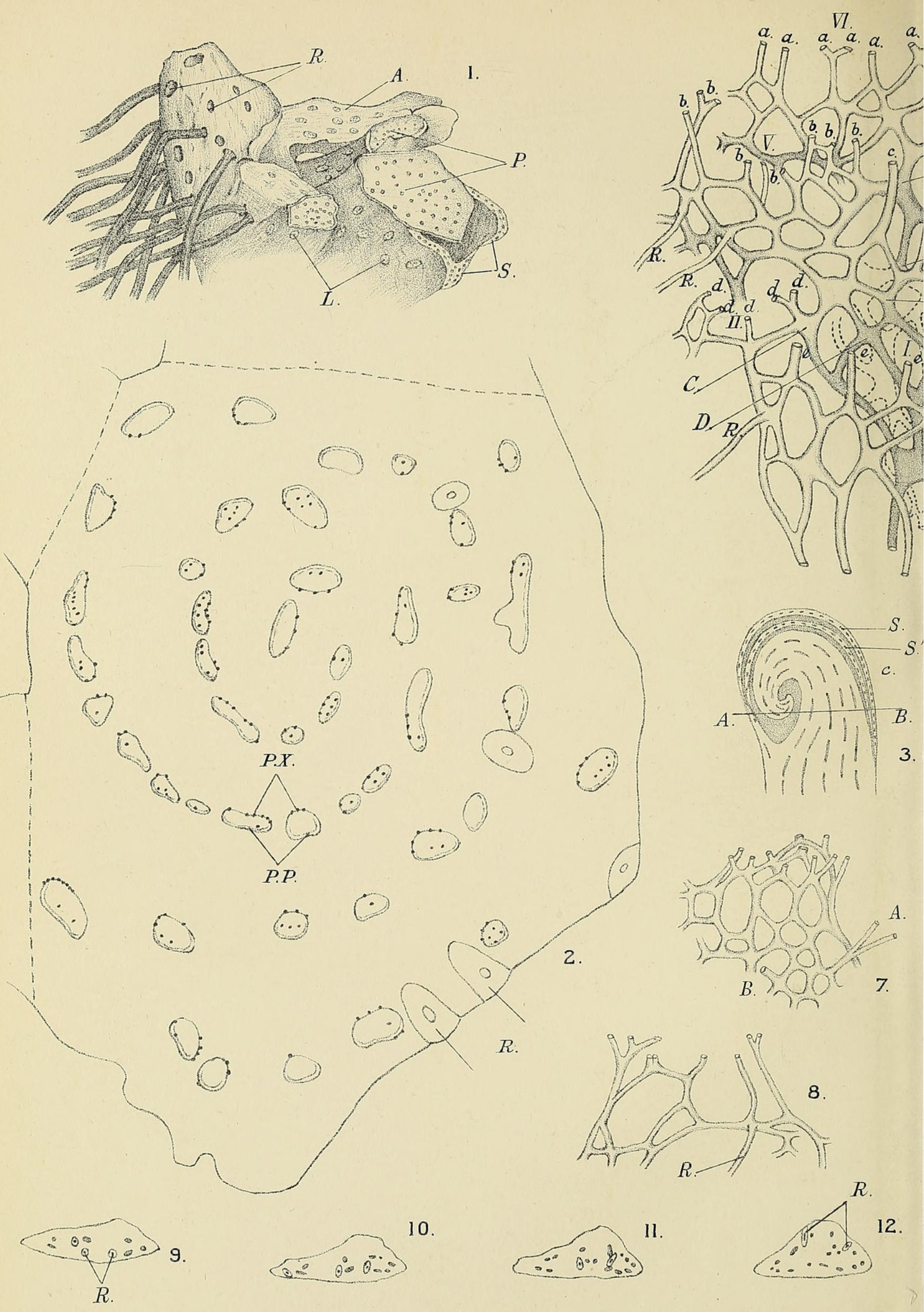

RF Shove, del 

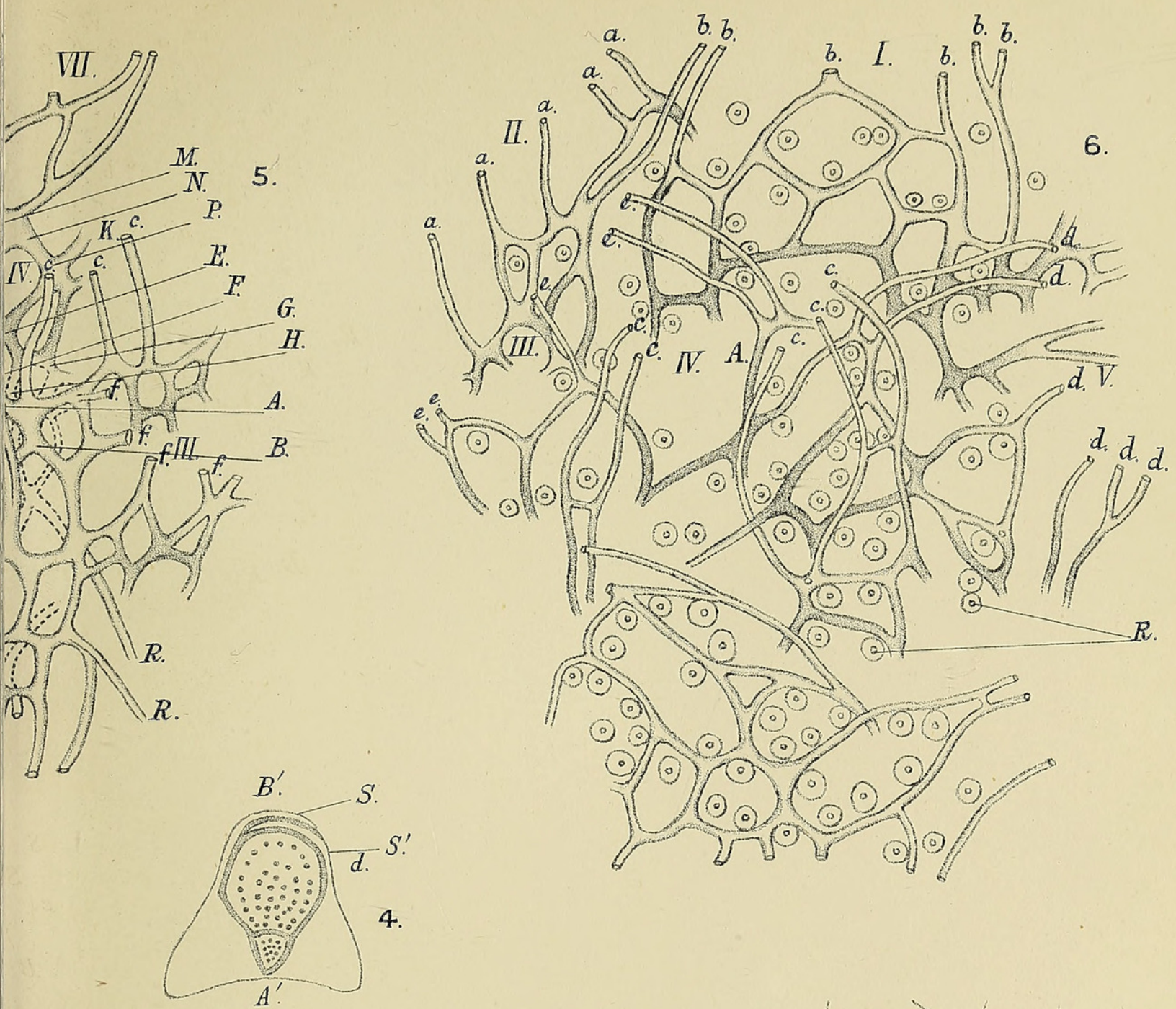

$R$.

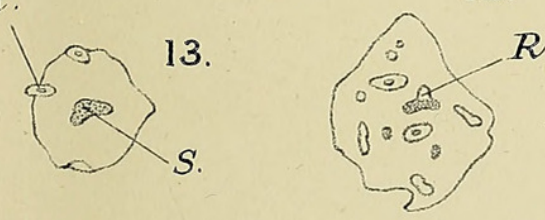

\& 14

800

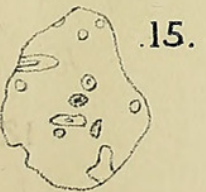

$R$.

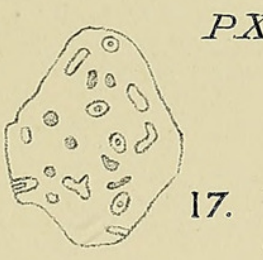

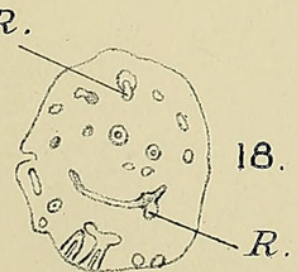

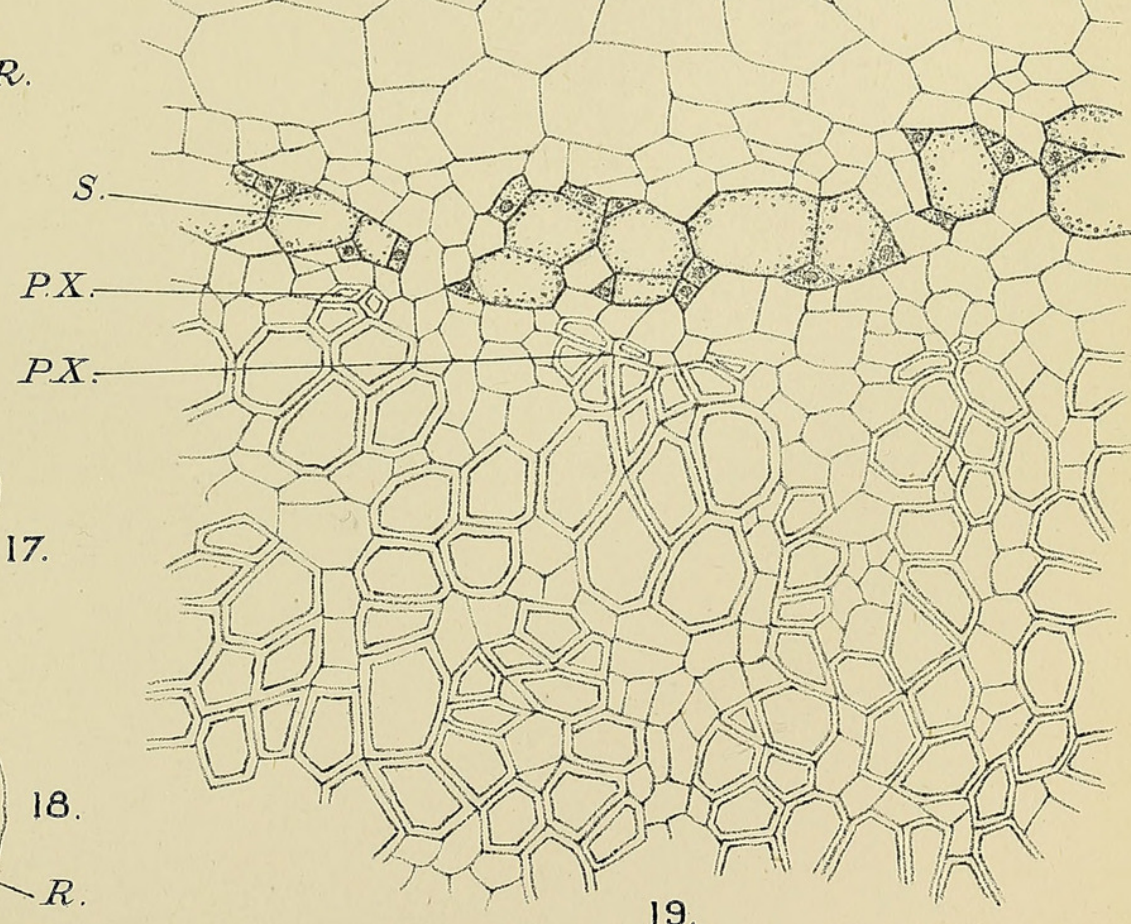

19 

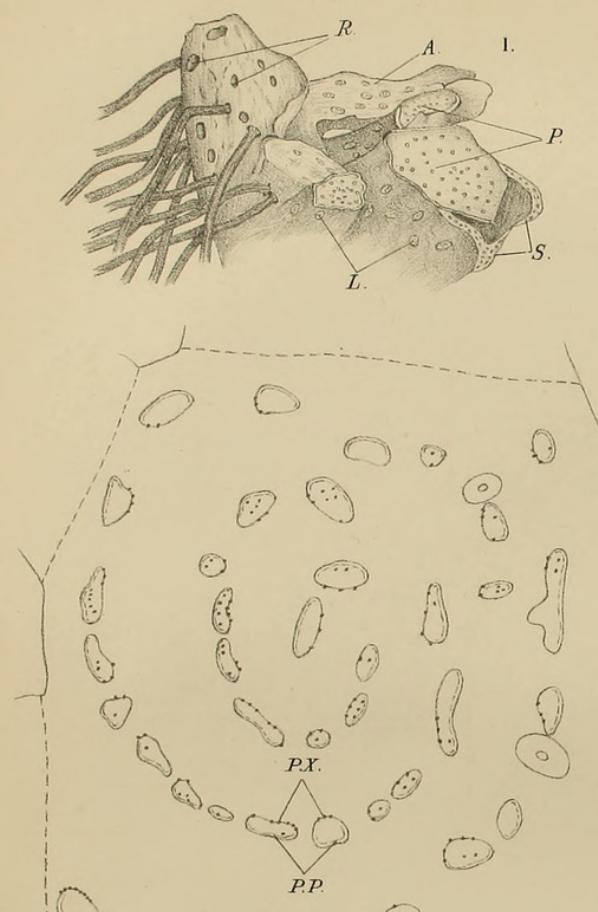

(.) $\because P$ C.

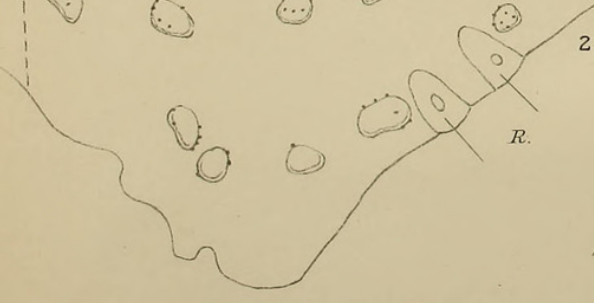

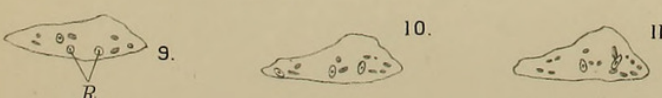

RF Shove, del
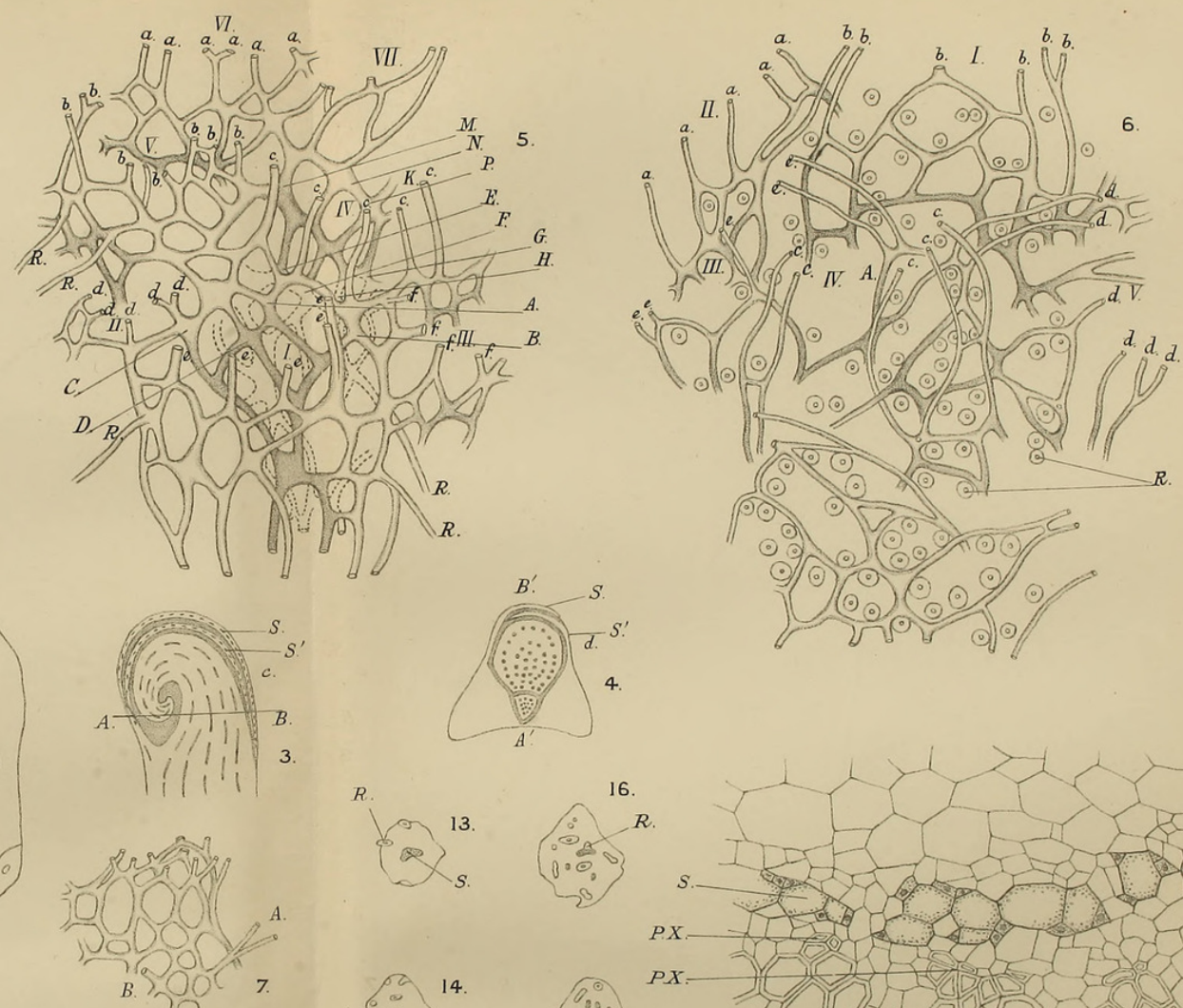

16.
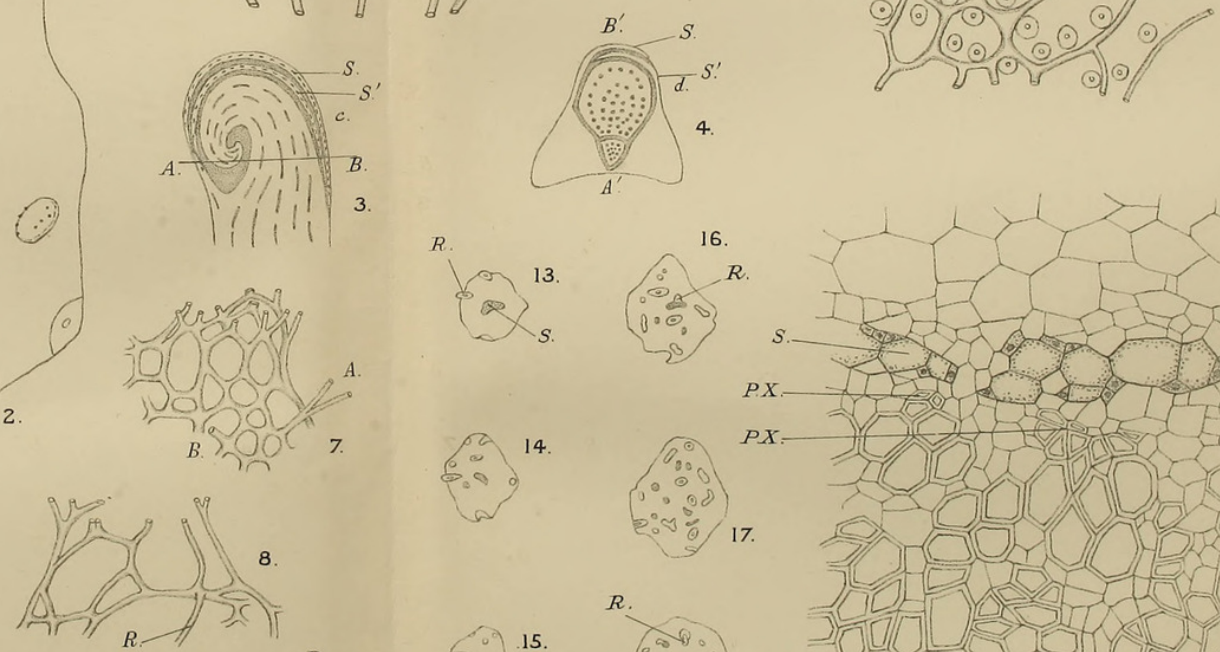

$R$
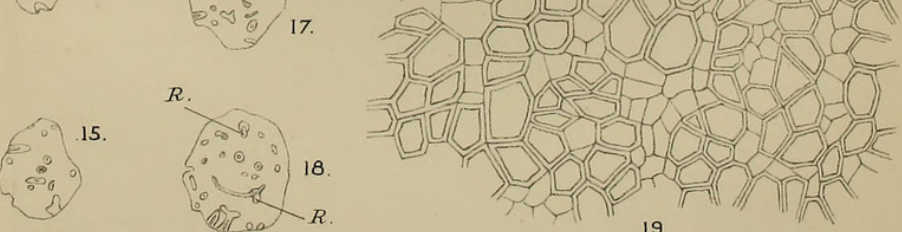

University Press, 0xford 

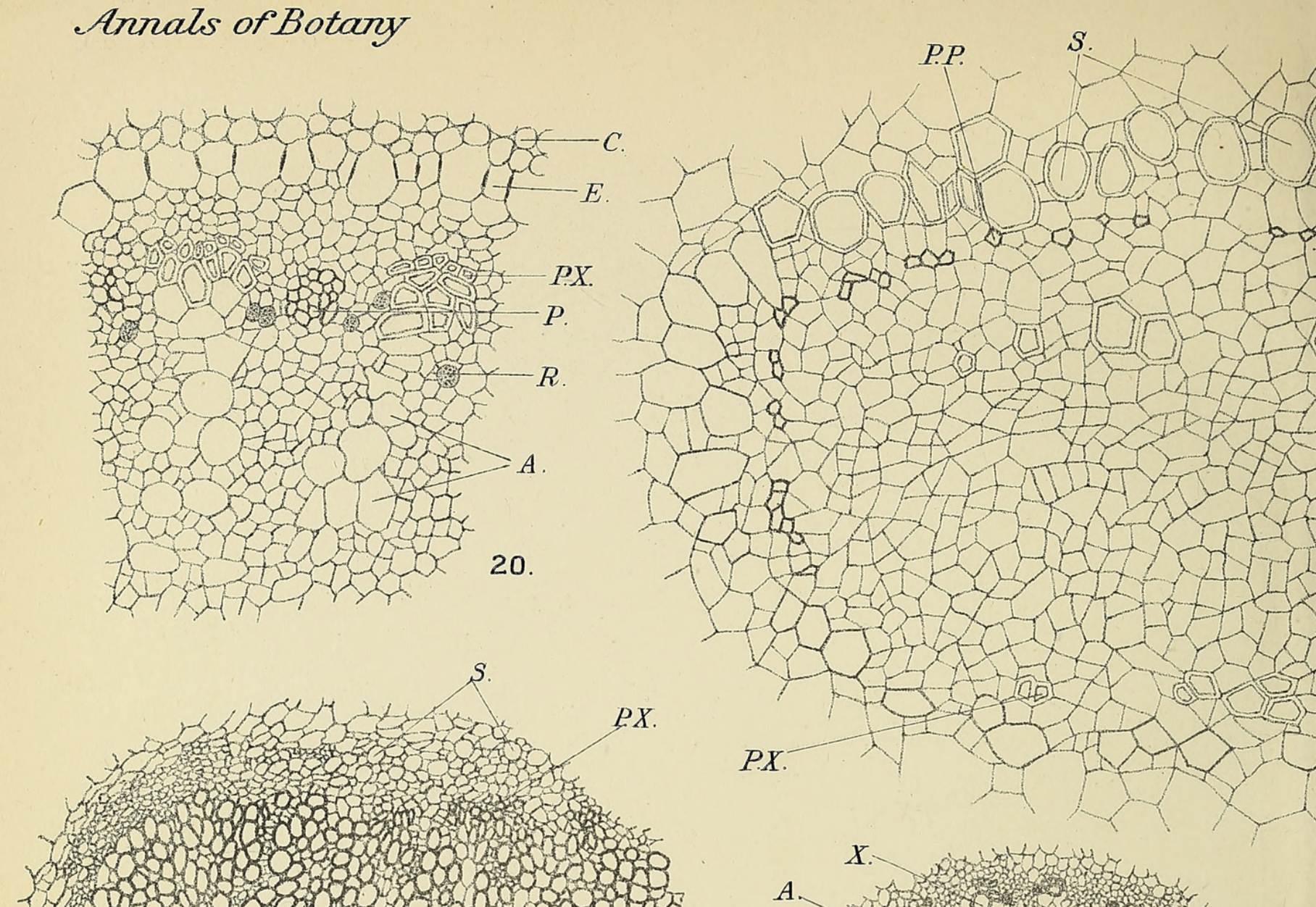

Ga

301 .

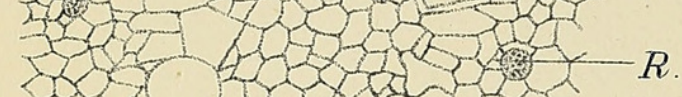

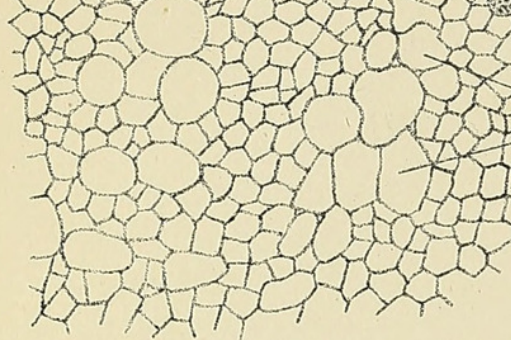

$S$.

K

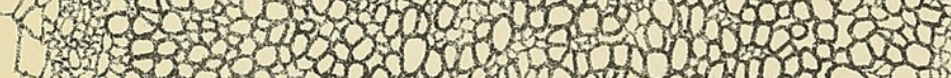

Y

- Lof

A.

i. 1 .
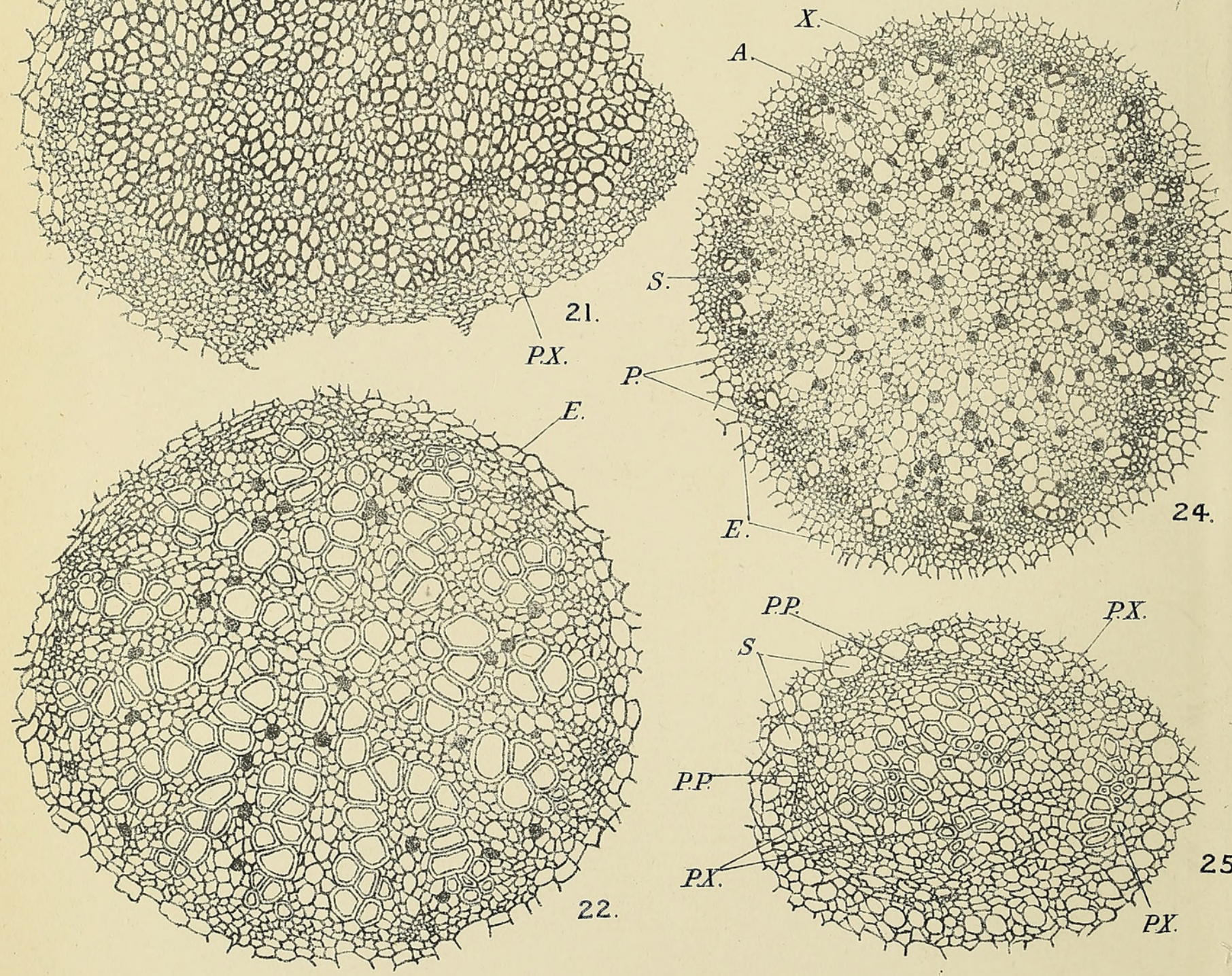

R.F.Shove, del

W.Tams, phot. 


\section{Annals of Botany}

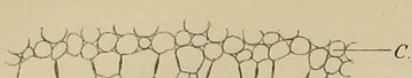

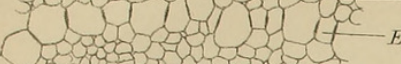

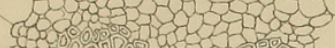

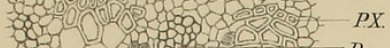
30

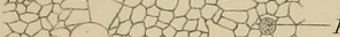

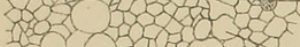

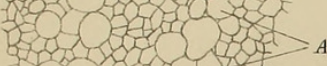
सेख्य है 135 A सितिक्षित

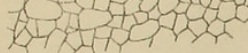

\section{0.}
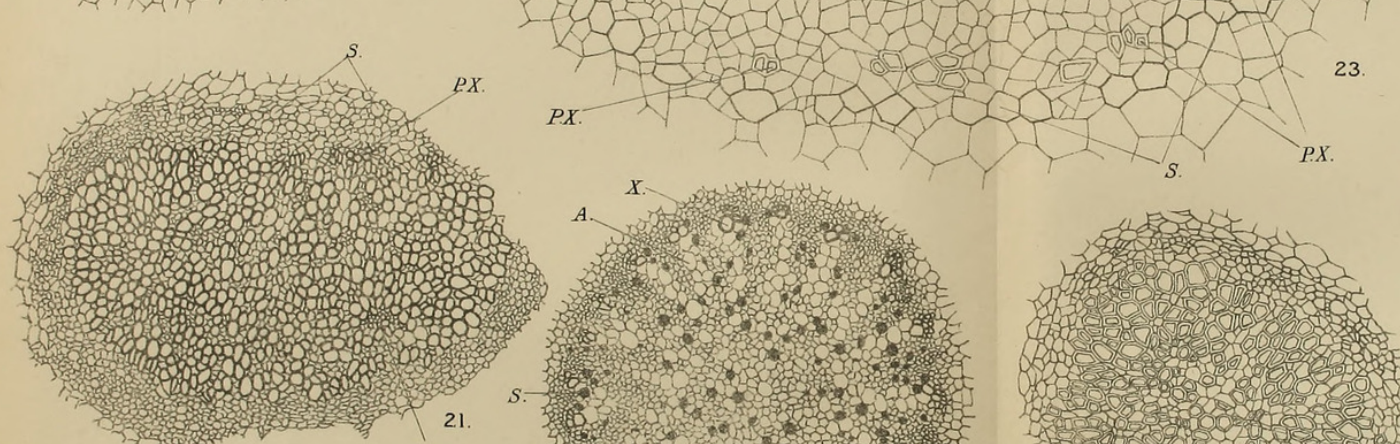

1210 Ta)

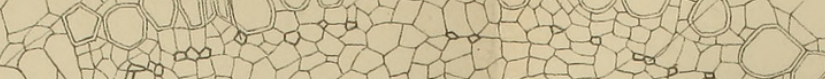
$12=40$.

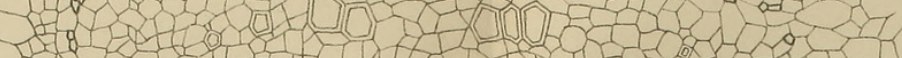
1 aे से से I.

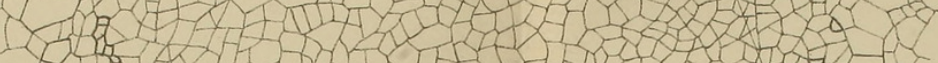
(1) 12 tी
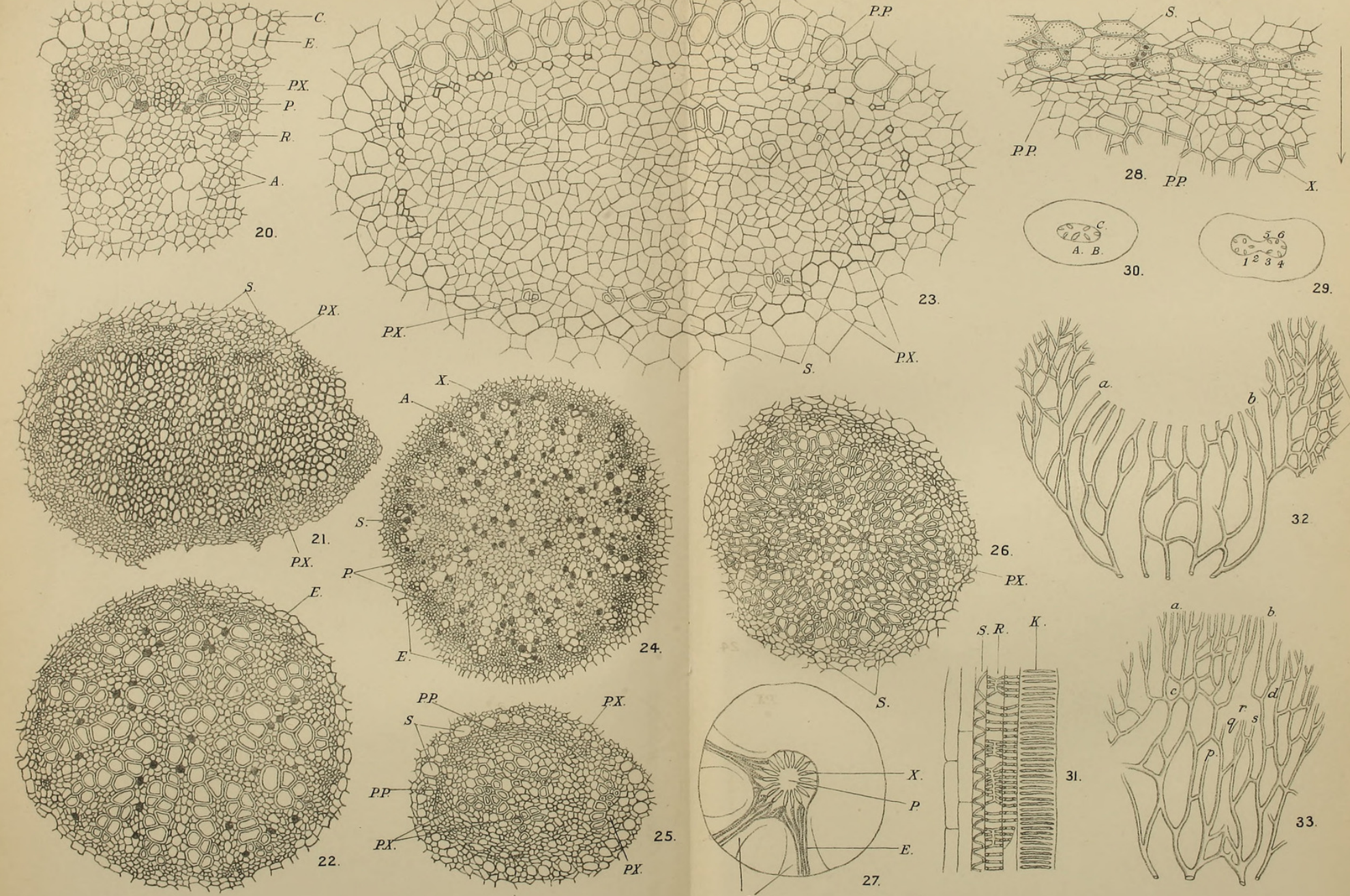

$P X$
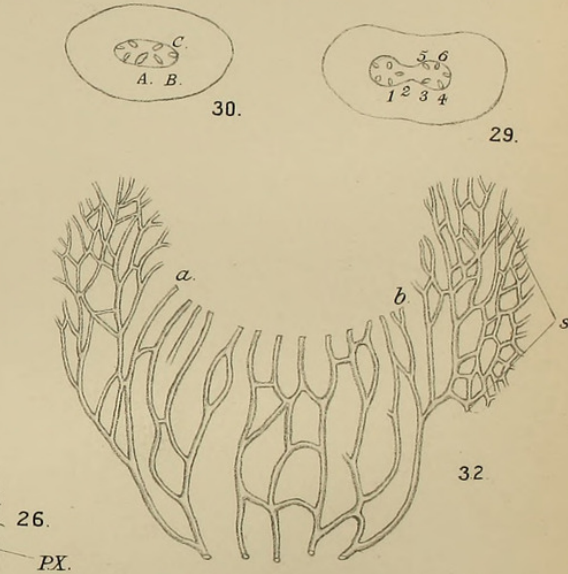

RF.Shove, del
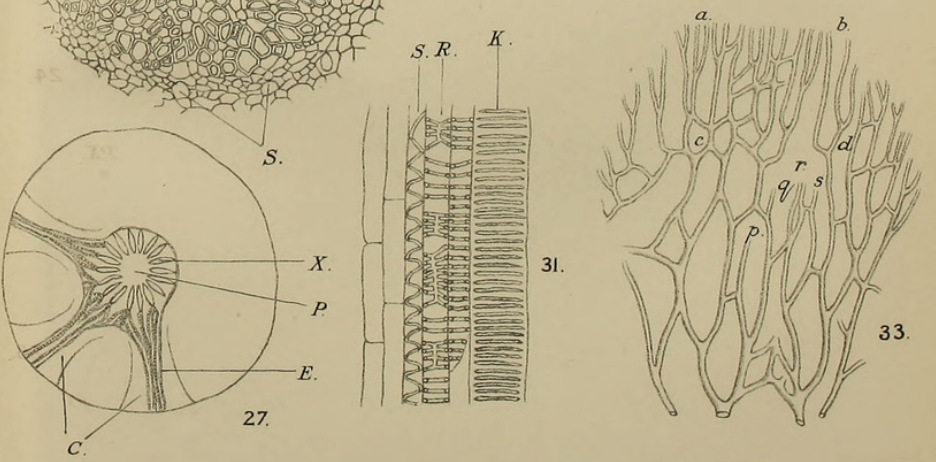

University Press, Oxford 


\section{$2 \mathrm{BHL}$ Biodiversity Heritage Library}

Shove, R. F. 1900. "On the structure of the stem of Angiopteris evecta." Annals of botany 14, 497-525. https://doi.org/10.1093/oxfordjournals.aob.a088789.

View This Item Online: https://www.biodiversitylibrary.org/item/238259

DOI: https://doi.org/10.1093/oxfordjournals.aob.a088789

Permalink: https://www.biodiversitylibrary.org/partpdf/318596

\section{Holding Institution}

Smithsonian Libraries

\section{Sponsored by}

Biodiversity Heritage Library

\section{Copyright \& Reuse}

Copyright Status: Not in copyright. The BHL knows of no copyright restrictions on this item.

This document was created from content at the Biodiversity Heritage Library, the world's largest open access digital library for biodiversity literature and archives. Visit BHL at https://www.biodiversitylibrary.org. 